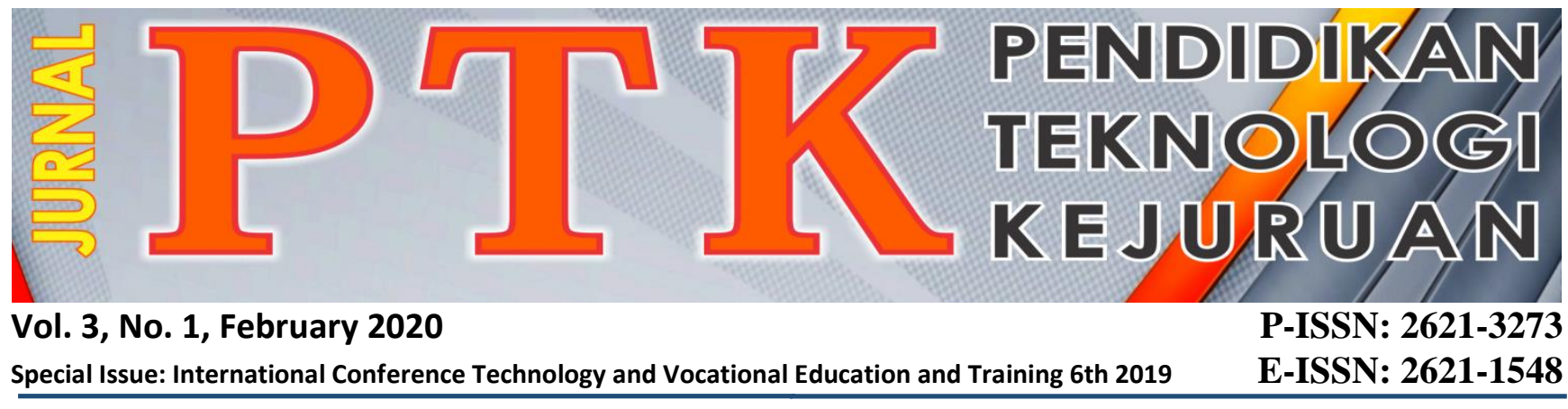

\title{
VALIDATION OF MEDIA INTERACTIVE LEARNING IN VOCATIONAL HIGH SCHOOL
}

\author{
Devri Ramdhan Apriyus, Kasman Rukun, Asrul Huda, Satria Ami Marta \\ Faculty of Engineering, Universitas Negeri Padang \\ Corresponding author, e-mail: devriramdhanapriyus01@gmail.com
}

\begin{abstract}
This research is motivated by the need for the media to learn that promote interaction and understanding of learning. The purpose of this research was: 1) to produce interactive learning media on Basic Graphic Design subjects at vocational high school. 2) Determining the validity of interactive learning media on Basic Graphic Design subjects at vocational high school. The method used is a Research and Development ( $R$ \& D). The development Model used is 4-D (Four-D). The 4-D consists of four stages, namely discovering, designing, developing and disseminating. The subjects of research conducted were material experts and media experts. The instrument used to measure the form of validity is the questionnaire responses. The validity of interactive learning media is assessed from two aspects namely media feasibility and feasibility aspects of the matter. The results of this research indicate that interactive learning media on Basic Graphic Design subjects is considered valid as seen from the average value of media validation by 0.87 and the average result of 0.85 material validation. Based on the results of the validation of the interactive learning media on Basic Graphic Design subjects are feasible for use in assisting the learning process.
\end{abstract}

Keywords: Validation of Interactive Learning Media, Basic Graphic Design

Copyright (c) 2020 JPTK. All rights reserved

\section{INTRODUCTION}

The need for science and technology that can enhance students' knowledge or insight with the help of technology in learning. The function of information and communication technology in learning, in addition to ease of learners in the study also had a considerable influence function for a teacher or educator, especially in the use of the facility to enrich teaching skills [1]. Thus, the function of science and technology in teaching and learning can help and influence to make learning to be more qualified.

Learning media includes physical tools that are used to convey the contents of teaching materials. Learning media helps the effectiveness of learning in order to encourage new knowledge, motivation and stimulation of learning activities and even bring mental effect on learners [2]. Interactive multimedia is a multimedia equipped with a controller that can be operated by the user so that the user can select what is desired for subsequent processing [4] Media
Learning is one aspect supporting the success of learning process [1].

The constraints or difficulties in learning the Basics of Graphic Design at SMK Negeri 1 Batipuh is difficult students understand the learning materials are conveyed using print modules, So there is hope Interactive learning media can help the learning process so that students can understand well the problems of learning, student motivation can be improved, interaction during the learning process is able to achieve the learning objectives and learning outcomes of students who are able to be improved. Before the media used and implemented in the classroom, the media is necessary to test the feasibility of some of the assessment indicators and aspects of the media aspects of the material. Thus, the necessary validation of interactive learning media on the subjects of Graphic Design Basics class $\mathrm{X}$.

\section{METHODOLOGY}

The model development of interactive learning media on the subjects of Graphic Design Basics 
development model 4-D (four-D). 4-D model of the development consists of four main stages, namely: (1) Determine, (2) design, (3) Develop and (4) Dissemination [5]. This model was chosen because it has a simple procedure, has a systematic procedure and according to the research problem that researchers do. The methods of research and development or in Research and Development is a research method that is used to produce a specific product and test the effectiveness of the product. [6]

\section{A. Determine}

The implementation of the study begins with the define phase aiming to find out the basic problems needed in the development of interactive media on the subject of Basic Graphic Design. The actions are taken in the define phase, namely, first, analysis of Basic Graphic Design subjects that requires learning media such as video, audio, simulation, and animation so that the obstacles faced by students with media can maximize learning activity. Second, students 'analysis that understanding students' obstacles in Basic Graphic Design lessons require the creation of interactive media to support Basic Graphic Design learning filled with teaching materials following Basic Competencies and Core Competencies. Third, Task Analysis, the main tasks of the students during the Basic Graphic Design learning process, additional skills and learning material assignments following the subject of Basic Graphic Design. Fourth, the concept of analysis, identifying the concepts that will be taught following the Basic Graphic Design material and arranged systematically and in detail and Fifth, setting Instructional Objectives, per formulation of learning objectives summarized from the analytical task and analytical concepts to define indicators. learning achievement in Basic Graphic Design subjects following learning

\section{B. Design}

This stage aims to prepare the prototype media, this stage consists of three steps as follows: first, the selection of the selected media, the media following the phase were determined by a variety of media such as video, audio, simulations, and animations can help students in the achievement of basic competence. Secondly, the Format Selection, Format selected in making instructional media design media content from the learning content through the evaluation of learning writing Graphic Design Basics. Third, the initial draft, the preliminary draft is planning, drawing and sketching media of some component separated into a coherent whole and has a function.

\section{Develop}

At this stage, the validity test of the use of instructional media that has been developed to assess whether the developed media can be used following expectations can encourage motivation, interaction, understanding learning and student learning outcomes.

\section{Disseminate}

At this stage of an interactive learning media that has been eligible to spread with a larger level to determine its influence in the learning process

\section{RESULT AND DISCUSSION}

The media that was developed is an interactive learning media that helps teachers and students in the learning process so that abstract material can be concrete in the basic subjects of graphic design. To determine the extent of the validity of the interactive learning media on basic graphic design subjects using a validity test measured from two aspects, (1) material aspects, (2) aspects of media use.

Data were analyzed by using the results of the validity coefficient Aiken's V, Aiken been formulating Aiken's V for calculating Content Validity Coefficient based on the assessment of an expert panel of $n$ people on the item regarding the extent to which these items represent the measured construct [7]. Next, the average score is searched by the following steps:

a. Scoring answer with a number between 1 (very not represent or irrelevant) until number 5 (very represent or very relevant).

b. Summing the scores of each validator for all indicators.

c. Scoring percentage of the validity of the formula

$V=\Sigma S /[N(C-1)]$

Description:

$\mathrm{V}=$ Index of Validity

$\mathrm{s}=\mathrm{r}-\mathrm{Lo}$

$\mathrm{n}=$ number of validators or assessment panels

Lo $=$ the lowest validity rating Number

(in this case $=1$ )

$\mathrm{c}=$ the highest validity rating number

(in this case $=5$ )

$\mathrm{R}=$ number given by a validator

Based on the results of expert judgment conducted, Aiken's V coefficient of the validity of the items assessed is in the range of 0.60 to 1.0, high decision and very high rules. Thus, the validity coefficients of these experts can qualify as a valid instrument and can be used in this research.

\section{A. Media expert validation}


The validation of this material was done by three people in graphic design basics of learning material experts. The purpose of this material validation was to know the accuracy and usefulness of interactive learning Media on basic graphic design subject was already by the needs of learning.

The results of the assessment of each aspect provided by the validator were analyzed using the statistical formula Aiken's V. The results obtained are validation values of the product design produced. Recapitulation validation of learning media aspects is summarized in Table 1.

Table 1. The Results of Validation of Interactive Learning Media on Basic Graphic Design subject

\begin{tabular}{cccc}
\hline No. & Experts & Assessment & Category \\
\hline 1. & Expert 1 & 0,93 & Valid \\
2. & Expert 2 & 0,84 & Valid \\
3. & Expert 3 & 0,86 & Valid \\
\multicolumn{2}{c}{ Average } & 0,87 & Valid \\
\multicolumn{2}{c}{ Category aspect } & & Valid \\
\hline
\end{tabular}

Based on table 1 shows that the result validation by expert's media of interactive learning media on basic graphic design subject indicates that the interactive learning media on basic graphic design has an average value of validity of $0.87 \geq 0.66$ hence interactive learning medium including was valid category.

\section{B. Material expert validation}

The validation of this material was done by three experts in basic graphic design learning material experts. The purpose of this material validation was to determine the accuracy and suitability of the learning materials that contained in the Interactive learning Media on basic graphic design was already by the needs of learning.

Validation performed by material experts is reviewed from the aspect of material quality, and the quality of learning. In the implementation of its validity, the material experts review the material in the Interactive learning Media on basic graphic design subject, then the expert gives the value to the material in the interactive media on basic graphic Design subject, the results Assessment of each aspect given the expert was analyzed by using the statistics formula of Aiken's V. The result was a validation value to the resulting product of design. The results of the validation recapitulation of the learning material aspects are summarized in table 2 below.

Table 2. The Data of Validation of Interactive Learning

Media Materials on Basic Graphic Design Subject

\begin{tabular}{cccc}
\hline No & Experts & Assessment & Category \\
\hline 1 & Expert 1 & 0,87 & Valid \\
2 & Expert 2 & 0,82 & Valid \\
3 & Expert 3 & 0,86 & Valid \\
& Average & 0,85 & Valid \\
\multicolumn{2}{c}{ Category aspect } & & Valid \\
\hline
\end{tabular}

Based on table 2, shows that the material validation results on interactive Learning Media basic graphic design subject have an average value of validity of $0.85, \geq 0.66$ then the material on interactive learning Media on basic graphic design including in the category valid. The learning media can lead to the interconnection between users and learning media with mutual influence and mutual action and reaction between one another in helping to convey learning material [2] [8]. Non-print teaching materials are developed teaching materials to enrich the student's understanding of the subject matter other than to fill a gap arising from cultural problems reading, time constraints and to address the diversity of learning styles of learners [9]. The use of multimedia in building the learning process at vocational student competencies [10]. In other words, it can be said interactive learning media is an intermediary tool that conveys the message that contains information about the subject matter with the media to help explain the material that is abstract into the concrete delivered to make the students more easily understood cause effects give every action and reaction.

\section{CONCLUSION}

Related on the results of a validation study of interactive learning media on Graphic Design Basics subjects has been done, the obtained test the validity of the response obtained from media quality rating of 0.87 with the category "Valid" and the quality of learning materials by 0.85 by category "Valid", thus valid media interactive learning is used in learning.

\section{REFERENCES}

[1] Budiman, Haris. Peran Teknologi Informasi dan Komunikasi dalam Penddikan. Raden Intan Universitas Islam Negeri Lampung. 2017. 
[2] Aqib, Zainal.. Model Media dalam Strategi Pembelajaran Konseptual (Inovatif). Bandung: Yrama Widya. 2014.

[3] Niken Ariani dan Dany Haryanto. Pembelajaran Multimedia di Sekolah: Pedoman Pembelajaran Inspiratif, Konstruktif dan Prosprektif. Jakarta: Prestasi Pustaka Publisher. 2010.

[4] Arsyad Azhar. Media Pembelajaran. Jakarta: Raja Grafindo Persada. 2013.

[5] Sugiyono. Pendekatan Metode Penelitian Kualitatif, Kuantitatif dan $R \& D$. Bandung: Alfabeta. 2012.

[6] Timpuslitjaknov. Metodologi Penelitian Pengembangan: Departemen Pendidikan Nasional. 2008.

[7] Azwar S. Metode Penelitian. Yogyakarta: Pustaka Pelajar. 2014.

[8] Lia Kamelia \& Adam Faroqi. Perancangan Dan Implementasi Pembelajaran Dairy Learning Menggunakan Dokeos. Jurnal Edisi Juli 2014 Volume VIII No. 1 - ISSN 19798911. 2014.

[9] Khaidir Rahman N. Pengembangan Media Pembelajaran Berbasis Website untuk Mata Pelajaran Programmable Logic Controller (PLC) pada SMK Darussalam Makassar. Jurnal Inspiraton, Volume 6, Nomor 2, Desember 2016: 105 -117. 2016.

[10] Hamonangan, tambunan \& efend, napitulu. efektivitas interaktif model pembelajaran berbasis multimedia dalam mekanika teknik. Pendidikan Internasional Studi, Vol 9, No.10;2016 ISSN 191-9020E-ISSN 19139039. Diterbitkan Oleh Kanada Pusat Sains dan Pendidikan. 2016.

[11] S. Syahril, N. Jalinus, R. A. Nabawi, and Y. Arbi, "The Create Skills of Vocational Students to Design a Product: Comparison Project Based Learning Versus Cooperative Learning-Project Based Learning," Adv. Soc. Sci. Educ. Humanit. Res., vol. 299, no. 5th UPI International Conference on Technical and Vocational Education and Training (ICTVET 2018) The, pp. 316-320, 2019. 